five years later was always in the presence of settlers who had been in the region for the whole of the time elapsing after Black Hawk's death. They were cognizant of the fact and presumably ready and willing to impart it to Barrows and all concerned.

Black Hawk's body was in its grave until July 3, 1839, when it was stolen, as related by James $\mathrm{H}$. Jordan in an interview with D. C. Beaman (ANnals of Iowa, XIII, p. 130) and other authorities.

Now, although Barrows' survey was disputed and canceled by the General Land Office, and Jeffries' resurvey has the effect of the authority of law, yet Jeffries' work being done July 10 to 28 , in 1846 , omitted all historical references incidental to the strict descriptions, measurements and location of lands, and it would seem, did not interfere with the reliability of Barrows' record of the fact and location as to Black Hawk's place of death nor that of his burial.

\title{
POLITICAL, CHANGES IN OUR STATE GOVERNMENT
}

The complete political turnover made in the state offices at the November, 1932, election has caused inquiry as to political changes of the state on previous occasions.

The majority of the early settlers of the territory of Iowa were Democrats. The fact that southerners somewhat predominated among them did not altogether account for the Democratic preponderance, as Democrats came to Iowa from the North as well as from the South, and Whigs came from the South, a few of them, as well as from the North.

-The first territorial governor was Robert Lucas, 1838 to 1841, a Democrat of Ohio, appointed by President Van Buren. The sccond territorial governor was John Chambers, 1841 to 1845, a Whig of Kentucky, appointed by President William Henry Harrison. The third and last territorial governor was James Clarke of Burlington, Iowa, a Democrat, appointed by President Polk in 1845. He served until Iowa became a state in 1846 .

During territorial times, 1838 to 1846 , there were eight assemblies. Their membership and political classifications were as follows : ${ }^{\mathrm{T}}$

\footnotetext{
1For the political alignments of the legislative assemblies we have followed Gue in his History of Iowa, Vol. III, pp. $442-66$.
} 
First Legislative Assembly, November 12, 1838.

Council-Democrats, 7; Whigs, 6.

House--Democrats, 17; Whigs, 8.

Second Legislative Assembly, November 4, 1839.

Council-Democrats, 7; Whigs, 6.

House-Democrats, 15; Whigs, 11.

Third Legislative Assembly, November 2, 184.0.

Council-Democrats, 7 ; Whigs, 6.

House-Democrats, 15; Whigs, 11.

Fourth Legislative Assembly, December 6, 1841.

Council-Democrats, 8; Whigs, 5.

House-Democrats, 16; Whigs, 10.

Fifth Legislative Assembly, December 6, 1842.

Council-Democrats, 7; Whigs, 6.

House--Democrats, 15; Whigs, 11.

Sixth Legislative Assembly, December 4, 1843.

Council-Democrats, 6 ; Whigs, 7.

House-Democrats, 19 ; Whigs, 7 .

Seventh Legislative Assembly, May 5, 1845.

Council-Democrats, 11; Whigs, 2.

House-Democrats, 16; Whigs, 10.

Eighth Legisiative $\Lambda$ ssembly, December 1, 184.5.

Council-Democrats, 11; Whigs, 2.

House-Democrats, 22; Whigs, 10.

Under the state government, beginning in 1846 , the people of Iowa had their first chance to elect their own governor. Ansel Briggs of Jackson County, a Democrat, was the first governor. He served from 1846 to 1850 , as four years was the length of the term for governor under the first constitution. The second was Stephen Hempstead of Dubuque, also a Democrat, and he served from 1850 to 1854 . Then there came a turnover. James W. Grimes, a Whig, of Burlington, was elected and served from 1854 to 1858 . During this administration the Republican party was organized and he became allied with that party. Since then until 1933, all of Iowa's governors but one, Horace Boies, 1890 to 1894, were Republicans. Therefore Iowa in her eighty-six years as a state has had three Democratic governors, Briggs, Hempstead, and Boies, one Whig, Grimes, and twenty Republicans.

'Tracing the political complexion of the legislative branch of the government of the state we find it rather closely followed the changes in the governor's office. The early assemblies were as follows: 
First General Assembly, November 30, 1846.

Senate-Democrats, 12; Whigs, 6.

House-Democrats, 17; Whigs, 23.

Second General Assembly, December 4, 1848.

Senate-Democrats, 18; Whigs, 8.

House--Democrats, 28; Whigs, 11.

Third General Assembly, December 2, 1850.

Senate-Democrats, 13; Whigs, 5.

House-Democrats, 34; Whigs, 5.

Fourth General Assembly, December 6, 1852.

Senate-Democrats, 20; Whigs, 11 .

House-Democrats, 40; Whigs, 23.

Fifth General Assembly, December 4, 1854.

Senate-Democrats, 17; Whigs, 14.

House-Democrats, 31; Whigs, 40.

It is noticed in the above that the Democrats in 1854 lost the lower or popular branch of the legislative department. It did not regain it for a period of seventy-nine years, or until the session of 1933. There was once that it was in the balance, 1890, when the membership was Republican, 50; Democrats, 45; Independents, 5. The Independents voting with the Democrats, the five weeks' deadlock was broken by giving the speaker to the Democrats, the speaker pro tem and chicf clerk to the Republicans, and the committee chairmen being divided between the two parties. The election resulting in the choice of this House was the one that chose Governor Boies for his first term. The Democrats also lost the Senate in the Sixth General Assembly, 1856. They regained it in the Twenty-fourth general Assembly, 1892, in the second election of Governor Boies, the division being Republicans, 24; Democrats, 25; Populist, $1 .^{2}$ With that one exception the Senate had a Republican majority from 1856 to 1931 .

The office of lieutenant governor was not created until the second constitution was adopted in 1857. Oran Faville of Mitchell County, a Whig, was the first elected to that office. Since then all the lieutenant governors have been Republican except Samuel L. Bestow of Lucas County, a Democrat, who was elected in Governor Boies's second election, 1891, and he presided over the Senate of the Twenty-fourth General Assembly, 1892.

2Senate Journal, 1892, p. 12. 
The principal exceutive offices of the state government were held by Democrats from 1846 to 1854 , but after that they went to the Whigs and by 1858 to the Republicans. Since 1856 the offices of secretary of state, auditor of state, and treasurer of statc have been continuously filled by Republicans until December 31 , 1932, a period of seventy-seven years.

The judges of the Supreme Court under the territorial form of government were appointed by the president. They were Charles Mason, chief justice, and Thomas S. Wilson and Joseph Williams, associate justices, all Democrats. Under the state government and under the first constitution, 1846 to 1857 , the judges of the Supreme Court were elected by joint sessions of the General Assembly. After the adoption of the Constitution of 1857 they were elected by the voters of the state. The bench first consisted of three members, which has been increased from time to time until there are now nine members. Besides Charles Mason and Thomas S. Wilson, territorial judges who served briefly on the organization of the Supreme Court of the new state, there were Joseph Williams, S. Clinton Hastings, John I. Kinney, George Greene, and Jonathan C. Hall, five in number, all Democrats, and reaching from 1847 to 1854 . Then there came a political turnover and the following four, William G. Woodward, Norman W. Isbell, Lacon D. Stockton, and George G. Wright were elected as Whigs. From that time until 1932, all men who occupied positions on that tribunal are listed as Republicans except LeVega G. Kinne, a Democrat, who was elected in 1891, the year of Governor Boics's second election. Judge Kinne served six years.

Numerically there have been on the supreme bench of our state eight classed as Democrats, four as Whigs, and thirtyseven as Republicans.

Three general political periods have appeared in the state. The first was Democratic from 1846 to 1854 , the second was Whig from 1854 to 1856 , and the third was Republican from 1856 to 1932, with a partial break in a period from 1890 to 189.4 when the governor, for four years, lieutenant governor, for two years, the state superintendent of public instruction for two years, the Senate for one session, and a judge of the Supreme Court for one term of six years, were Democratic. 
Copyright of Annals of Iowa is the property of State of Iowa, by \& through the State Historical Society of Iowa and its content may not be copied or emailed to multiple sites or posted to a listserv without the copyright holder's express written permission. However, users may print, download, or email articles for individual use. 